\title{
CORN AND GRAIN SORGHUM RESPONSE TO LIMITED IRRIGATION, DROUGHT, AND HAIL
}

\author{
N. L. Klocke, R. S. Currie, I. Kisekka, L. R. Stone
}

\begin{abstract}
A field study was conducted for eight years in southwest Kansas near Garden City to measure the response of corn and grain sorghum to limited irrigation in the region. An irrigation variable was imposed on each crop, with six irrigation treatments from full irrigation scheduled to minimize soil water deficits to minimal or no irrigation. To create differences in the amount of irrigation across treatments, the time between 25-mm irrigation events increased as irrigation decreased. A historic drought occurred during 2011 and 2012 when cropping season precipitation, the precipitation occurring from the harvest of the prior crop through the harvest of the next crop, was $60 \%$ of the 30-year average. Except for 2008, average cropping season precipitation was $8 \%$ above average during the prior six years. Linear regressions of corn and sorghum grain yields (GY) and dry matter yields (DMY) versus crop evapotranspiration (ETc) from all years combined, except hail damaged sorghum in 2005, produced $R^{2}$ values from 0.71 to 0.79 . One hailstorm during 2005 damaged sorghum to the extent that yields did not vary with respect to ETc or irrigation. Hail events in 2005 and 2006 occurred at nearly the same growth stage for corn caused lower leaf area and yields than during other wet years with no hail. Using quadratic regressions, corn yields during wet years with no hail, wet years with hail, and dry years had distinctly different dependence on irrigation. Although sorghum yields during wet years tended to increase as irrigation increased, sorghum's response to irrigation was less than for corn during the same years. During dry years, sorghum and corn were highly dependent on irrigation. Net economic returns (NR) of continuous corn, continuous sorghum, cornsorghum, corn-wheat, and sorghum-wheat rotations were each higher with a year receiving average precipitation $(460 \mathrm{~mm})$ than a year receiving $60 \%$ of average precipitation $(280 \mathrm{~mm})$. The NR of continuous corn dominated the rest of the rotations when irrigation was more than 230 to $330 \mathrm{~mm}$ in the dry year and 90 to $180 \mathrm{~mm}$ in wet year. As farmers choose crop rotations, they need to consider management factors and crop tolerance to soil water stress in addition to potential NR.
\end{abstract}

Keywords. Corn, Crop production functions, Deficit irrigation, Irrigation, Irrigation management, Limited irrigation, Sorghum, Wheat.

I

rrigators in regions like the Great Plains of the United States may need to consider alternative crop selection and management systems as fresh water supplies decline and more severe droughts. Irrigators can adjust their crop selections and water management to sustain profitable economic returns from the remaining water by: (1) reducing water applications to the same crop, thus incurring water deficits during all or part of the growing season, (2) growing crops that use less water to match the water supply, (3) reducing area for crops with high water demand and substitute crops with lower water demand into crop rotations, or (4) reducing total irrigated area and fallowing the remaining area (Martin et al., 1989). One example of matching water supplies with cropping

Submitted for review in June 2014 as manuscript number SW 10810; approved for publication by the Soil \& Water Division of ASABE in October 2014.

The authors are Norman L. Klocke, ASABE Member, Emeritus Professor, Randall S. Currie, Associate Professor, and Isaya Kisekka, ASABE Member, Assistant Professor, West Central Research Extension Center, Kansas State University, Garden City, Kansas; and Loyd R. Stone Professor, Department of Agronomy, Kansas State University, Manhattan, Kansas. Corresponding author: Norman L. Klocke, 4500 East Mary Street, Garden City, Kansas, 67846; phone: 620-276-8286; e-mail: nklocke@ksu.edu.

choices is the use of corn and/or grain sorghum because grain sorghum can substitute for corn in livestock feeding and ethanol producion. Corn has been the preferred crop of the two for irrigation because of its greater economic return than sorghum. Typically, corn is grown as a dryland (rainfed-only) crop in the northern Great Plains but as an irrigated crop further south. Sorghum is grown as dryland crop in the central Great Plains but as an irrigated crop in the southern Great Plains. Sorghum can tolerate more soil water stress than corn, which gives it an advantage when water supplies are limited. Corn can survive soil water stress during vegetative growth but is sensitive to water stress during reproduction, which leaves it vulnerable when irrigation from limited water cannot overcome earlier soil water depletions.

Choosing between corn and sorghum in irrigated production based on economic return can produce different outcomes with changes in irrigation and precipitation. Klocke et al. (2006) developed the Crop Water Allocator, a tool to compare economic return from monoculture crops as well as crops grown in rotations given the land allocation to each crop in rotation, the yields generated by a range of irrigation and precipitation amounts, and operating costs for each rotation. Field studies cannot provide crop 
yield data for all possible amounts of irrigation and precipitation. However, data from field studies can generate response functions of yield with respect to evapotranspiration (ETc). Stone et al. (2006) used a model that calculated yields from a range precipitation and irrigation based on these crop productions functions, which were necessary to find the economic returns of crops with ample to minimal or no irrigation.

In afield study conducted from 2005-2009 yield responses of corn (Klocke et al., 2011) and sorghum (Klocke et al., 2012) to ETc and applied irrigation were measured. Furthermore, these results were compared with yield-ETc functions for corn from five additional field studies across the northern and southern Great Plains (Howell et al., 1989; Lyle and Bordovsky, 1995; Howell et al., 1995; Schneider and Howell, 1998; Klocke et al., 2007). Similar comparisons were derived for sorghum from four other field studies in the southern Great Plains (Allen and Musick, 1993; Schneider and Howell, 1995; Bordovsky and Lyle, 1996; Colaizzi et al., 2004).

The need for yield versus irrigation and ETc data, especially from multi-year studies, cannot be overemphasized. The results reported in Klocke et al. (2011 and 2012) covered five years when annual precipitation ranged from $118 \%$ to $90 \%$ of the 30-year average for that location. Data collection continued from 2010-2012 when annual precipitation during the final two years was $60 \%$ of the 30 -year average. These data were added to the earlier results and are reported here. The planned objectives were to find grain yield (GY) and dry matter yield (DMY) responses to ETc and irrigation from fully irrigated corn and sorghum to very limited or no irrigation. Hail events damaged corn during the first two years and damaged sorghum during the second year, which offered the opportunity to report yield results during hail years (Currie et al., 2008). The combined data from the wet years, dry years, and hail years were available for developing response functions reported here. Because corn and grain sorghum production is economically important for the region, the final objective was to predict net economic returns from corn and grain sorghum grown continuously or in rotations with full irrigation to no irrigation.

\section{Methodology}

\section{LOCATION AND SOILS}

This research was conducted at the Kansas State University Southwest Research-Extension Center near Garden City, Kansas. The soil type was a Ulysses silt loam (fine-silty, mixed, mesic Aridic Haplustoll) with $\mathrm{pH}$ of 8.1 and organic matter content of $1.5 \%$. The soil has an available water capacity of $0.18 \mathrm{~m} \mathrm{~m}^{-1}$ between field capacity (volumetric water of content of 33\%) and permanent wilting (volumetric water content of $15 \%$ ). The climate is semi-arid, with long-term average annual precipitation of $477 \mathrm{~mm}$, mean summer growing season daytime high temperature of $29^{\circ} \mathrm{C}$ (30-year average May through August), open-pan evaporation (April through September) of $1810 \mathrm{~mm}$, and a frost-free period of 170 days. During the study, average annual precipitation was $495 \mathrm{~mm}$, and reference ET (ETr) was $1537 \mathrm{~mm}$ as calculated with a Penman combination equation (Kincaid and Heermann, 1984; Lamm et al., 1994).

\section{Cropping System and IrRigation Protocol}

Four crops were grown in a five-year rotation of corncorn-wheat-sorghum-sunflower during 2005-2009. In 2010, another year of corn was substituted for sunflower. Although the entire crop sequence is not used in commercial production, it contains elements of irrigated and dryland cropping rotations. Corn, grown continuously from one year to the next, is the dominant irrigated crop; and sorghum, grown in the following summer after winter wheat, is the dominant dryland crop (Klocke et al., 2011; 2012). The data presented here are from the second year of corn in the five-year rotation where corn is the antecedent crop as is the case for continuous corn production. Corn was planted in early May into corn stubble and harvested in October; wheat was planted into corn stubble immediately after corn harvest and harvested in early July the following year; and sorghum was planted in mid-May, after 11 months of fallow following wheat harvest, and harvested in October. Each crop moved in rotation from one of the five crop blocks to the next every year, so every crop was present every year. Irrigation treatments were in the same physical location every year, meaning that the prior year's irrigation treatment effects carried over to the same irrigation treatment in the following year.

Irrigation treatments were designed to mimic water supply limitations in the region, where aquifer water yields dictate well pumping capacities, which, in turn, govern the frequency of irrigation events. Irrigation application depths need to be sufficiently large for efficient water delivery and sufficiently small to meet and not exceed soil infiltration rates. A common amount of water applied during one irrigation event is $25 \mathrm{~mm}$. Irrigation events for treatment 1 , the wettest treatment, were initiated when no more than $50 \%$ of the available soil water was depleted in the top $1.2 \mathrm{~m}$ of soil as measured in the field by neutron attenuation. If rainfall was sufficient to fill the soil profile in treatment 1 to field capacity, irrigation was delayed until the soil could hold at least $25 \mathrm{~mm}$ of water; furthermore, no more than two irrigation events per week were applied to treatment 1 to recognize pumping capacity limitations in the region. These protocols for irrigation treatment 1 , although more complex than those used in many irrigation studies, were intended to produce results that farmers can expect.

As with treatment 1 , five additional irrigation treatments received $25 \mathrm{~mm}$ of water during each irrigation event. The irrigation variable among the five treatments was achieved by increasing the time between irrigation events (table 1). The interval between irrigation treatments and total irrigation amounts varied from year to year because the amount of rainfall varied. All six irrigation treatments were replicated four times within each crop block, resulting in a randomized complete block experimental design.

Irrigation was delivered by a commercial four-span (44-m span width) linear-move sprinkler system (model 8000, Valmont Corp., Valley, Neb.), modified to deliver water to any combination of irrigation treatments. Details 
Table 1. Average number of days between irrigation events and equivalent daily irrigation rates from 2005 through 2012 .

\begin{tabular}{lcccccc}
\hline \multicolumn{1}{c}{ Irrigation Treatments } & 1 & 2 & 3 & 4 & 5 & 6 \\
\hline $\begin{array}{l}\text { Days between irrigation } \\
\text { events }\end{array}$ & 5.10 & 6.60 & 8.50 & 11.00 & 13.30 & 17.20 \\
$\begin{array}{l}\text { Irrigation application } \\
\left(\mathrm{mm} \mathrm{d}^{-1}\right)\end{array}$ & 4.90 & 3.79 & 2.94 & 2.27 & 1.88 & 1.45 \\
\hline & & \multicolumn{5}{c}{ Sorghum } \\
$\begin{array}{l}\text { Days between irrigation } \\
\quad \text { events }\end{array}$ & 6.30 & 8.20 & 8.50 & 13.30 & 13.50 & 15.30 \\
$\begin{array}{l}\text { Irrigation application } \\
\left(\mathrm{mm} \mathrm{d}^{-1}\right)\end{array}$ & 3.97 & 3.05 & 2.94 & 1.88 & 1.85 & 1.63 \\
\hline
\end{tabular}

of sprinkler configurations and combinations of application rates and travel speeds across irrigation treatments were previously reported (Klocke et al., 2003).

Crop production was managed with no-till methods; corn was planted directly into corn stubble and sorghum was planted directly into wheat stubble with $760 \mathrm{~mm}$ between each row. Because corn is sensitive to plant density, seeded populations increased across the six irrigation treatments with increasing levels of irrigation $(48,200,54,400,60,500,66,700,72,900$, and 79,100 plants $\left.\mathrm{ha}^{-1}\right)$. Planting the same population on all irrigation treatments could have reduced the potential yield with high irrigation and could increase the risk for crop failure with little or no irrigation. Sorghum was seeded with the same population in all irrigation treatments $\left(260,000\right.$ plants ha $\left.{ }^{-1}\right)$ to discourage plant tillering that would produce multiple heads rather than one head per plant and because sorghum is less sensitive to plant density than corn. Corn grain was hand-harvested from two adjacent 3-m-long rows. The drier plots were harvested first because they matured and dried earlier than the wet plots, spreading harvest over one week. Bird netting draped over a 3-m-long PVC structure was installed in each sorghum plot before seed set. Harvest samples were taken from plants within the structures. Sorghum heads were hand-harvested at maturity and airdried before threshing. Grain moisture content at harvest was measured to adjust yields to $15.5 \%$ moisture content for corn and 14\% moisture content for sorghum.

\section{EVAPOTRANSPIRATION AND SOIL WATER}

Reference evapotranspiration (ETr) was calculated with an alfalfa-referenced modified Penman model (Kincaid and Heermann, 1974; Lamm et al., 1994) using weather factors including maximum and minimum air temperature, relative humidity, solar radiation, and wind run (wind speed $\times$ time) from an automated weather station near the study site.

Volumetric soil water content $\left(\theta_{\mathrm{v}}\right)$ was measured biweekly to a depth of $2.40 \mathrm{~m}$ in $0.3-\mathrm{m}$ increments with neutron attenuation techniques (Evett and Steiner, 1995). Change in soil water from the start to the end of a sampling period (two weeks), rainfall, net irrigation, and estimates of drainage were used in a water balance to calculate ETc:

$$
\mathrm{ETc}=\mathrm{NI}+\mathrm{P}-\mathrm{R}-(\mathrm{SW} 2-\mathrm{SW} 1)-\mathrm{D}
$$

where, NI = net irrigation (water infiltrated) during the sampling period, $\mathrm{P}=$ precipitation during the sampling period, $\mathrm{R}=$ runoff or run-on during the sampling period (observed to be negligible), $\mathrm{D}=$ drainage during the sampling period, $\mathrm{SW} 2$ = total soil water at the end of the sampling period, and $\mathrm{SW} 1=$ total soil water at the beginning of the sampling period.

ETc was estimated for the days between plant emergence and the first soil water measurement with a crop simulation model (Klocke et al., 2010). See Klocke et al. (2010) for drainage calculation details.

\section{Economic Returns}

Net returns were calculated for continuous corn, continuous sorghum, corn-sorghum, corn-wheat, and sorghum-wheat rotations when equal land areas were devoted to each crop in years with 280 or $460 \mathrm{~mm}$ of precipitation. Calculations were repeated for growing season irrigation amounts from 25 to $525 \mathrm{~mm}$ in $50-\mathrm{mm}$ increments. Net returns (NR) were defined as:

$$
\begin{aligned}
& \text { Net Return }= \\
& \text { Commodity Price * Grain Yield - Operating Costs }
\end{aligned}
$$

NR is not equivalent to profit because fixed costs, assumed to be the same for all crops, are not part of the calculation. The Crop Water Allocator (Klocke et al., 2006) was used to perform the calculations for NR. Rather than using current commodity prices to compare net returns, relative NR (RNR) was calculated as the ratio of NR for each combination of crop rotation, irrigation, and irrigation and the maximum net return of all combinations. In this case, the maximum NR was $\$ 280 \mathrm{ha}^{-1}$ for corn receiving $430 \mathrm{~mm}$ of irrigation and $460 \mathrm{~mm}$ of precipitation.

\section{RESULTS \\ PReCiPITATION AND REFERENCE ET}

Dormant season precipitation occurred from the maturity of the previous crop until planting the following crop. Growing season precipitation occurred from planting through maturity of the following crop (table 2). Cropping season precipitation, the sum of dormant and growing season precipitation, was the total precipitation that potentially contributed to crop yields. Cropping season precipitation lasted 12 months for continuous corn and 14 months for sorghum following wheat. Cropping season precipitation was above average, in 2005, 2006, 2007, 2009, and 2010 and below average in 2008, 2011, and 2012 for both corn and sorghum. Sorghum received the extra benefit of May and June precipitation, an average of $189 \mathrm{~mm}$, during its dormant season. ETr (table 3) was consistently higher than average during the dormant, growing, and cropping seasons for the drought years, 2011 and 2012.

\section{YIELD RESPONSES FROM CROP EVAPOTRANSPIRATION}

Hail occurred on 4 July 2005 and 6 July 2006 near the end of corn's vegetative growth but prior to tasseling, causing leaf stripping and leaf loss (Currie and Klocke, 2008). In addition, above average rainfall occurred during 2005, 2006, 2007, 2009, and 2010 while below average rainfall occurred during 2008, 2011, and 2012, prompting the delineation of corn yield data into three groups: 
Table 2. Dormant season, growing season, and cropping season precipitation (mm).

\begin{tabular}{|c|c|c|c|c|c|c|}
\hline \multirow[b]{2}{*}{ Year } & \multicolumn{3}{|c|}{ Corn } & \multicolumn{3}{|c|}{ Sorghum } \\
\hline & $\begin{array}{l}\text { Dormant } \\
\text { Oct-Apr }\end{array}$ & $\begin{array}{l}\text { Growing } \\
\text { May-Sep }\end{array}$ & $\begin{array}{c}\text { Cropping } \\
\text { Oct-Sep }\end{array}$ & $\begin{array}{l}\text { Dormant } \\
\text { July-May }\end{array}$ & $\begin{array}{c}\text { Growing } \\
\text { Jun-Sep }\end{array}$ & $\begin{array}{l}\text { Cropping } \\
\text { July-Sep }\end{array}$ \\
\hline 2005 & 134 & 308 & 442 & 502 & 260 & 762 \\
\hline 2006 & 141 & $\overline{330}$ & $\overline{471}$ & $\overline{362}$ & 288 & $\overline{650}$ \\
\hline 2007 & $\underline{335}$ & $\overline{256}$ & $\overline{591}$ & $\underline{572}$ & $\overline{279}$ & $\overline{851}$ \\
\hline 2008 & 113 & 241 & 353 & 324 & 210 & 533 \\
\hline 2009 & 272 & 317 & $\underline{589}$ & 432 & $\underline{311}$ & 742 \\
\hline 2010 & 221 & 247 & 468 & 497 & 155 & 652 \\
\hline 2011 & $\overline{100}$ & $\overline{157}$ & $\overline{257}$ & $\overline{239}$ & 137 & $\overline{376}$ \\
\hline 2012 & 182 & 156 & 338 & 275 & 179 & 453 \\
\hline $2005-2012^{[\mathrm{a}]}$ & 187 & 251 & 438 & 400 & 227 & 627 \\
\hline $1981-2010$ & 163 & 326 & 489 & 410 & 250 & 660 \\
\hline
\end{tabular}

Values in bold, italics, and underlined are above the 2005-2012 average.

Table 3. Dormant season, growing season, and cropping season reference evapotranspiration (mm).

\begin{tabular}{|c|c|c|c|c|c|c|}
\hline \multirow[b]{2}{*}{ Year } & \multicolumn{3}{|c|}{ Corn } & \multicolumn{3}{|c|}{ Sorghum } \\
\hline & $\begin{array}{l}\text { Dormant } \\
\text { Oct-Apr }\end{array}$ & $\begin{array}{l}\text { Growing } \\
\text { May-Sep }\end{array}$ & $\begin{array}{l}\text { Cropping } \\
\text { Oct-Sep }\end{array}$ & $\begin{array}{l}\text { Dormant } \\
\text { July-May }\end{array}$ & $\begin{array}{l}\text { Growing } \\
\text { Jun-Sep }\end{array}$ & $\begin{array}{l}\text { Cropping } \\
\text { July-Sep }\end{array}$ \\
\hline 2005 & 487 & 1078 & 1565 & 1238 & 1073 & 2311 \\
\hline 2006 & 750 & $\overline{1072}$ & 1822 & 1618 & 992 & 2610 \\
\hline 2007 & $\overline{433}$ & 949 & $\overline{1382}$ & $\overline{1178}$ & 937 & $\overline{2115}$ \\
\hline 2008 & 586 & 926 & 1512 & 1363 & 881 & 2244 \\
\hline 2009 & $\overline{606}$ & 822 & 1428 & 1294 & 774 & 2068 \\
\hline 2010 & $\overline{431}$ & 974 & 1406 & 1069 & 1020 & 2089 \\
\hline 2011 & $\underline{714}$ & 1273 & 1987 & 1551 & 1225 & 2776 \\
\hline 2012 & $\overline{700}$ & $\overline{1343}$ & $\overline{2044}$ & $\overline{1697}$ & $\overline{1262}$ & 2959 \\
\hline $2005-2012^{[\mathrm{a}]}$ & $\overline{588}$ & 1055 & $\overline{1643}$ & $\overline{1376}$ & $\overline{1021}$ & 2397 \\
\hline
\end{tabular}

Underlined and bold values are above the 1981-2010 averages.

(1) years with hail events and above average cropping season precipitation; (2) years with above-average cropping season precipitation and no hail; or (3) years with belowaverage cropping season precipitation and no hail. Leaf area index (LAI), total leaf area divided by ground area, increased as irrigation amount increased due in part to the increase in plant population as irrigation increased (fig. 1). This was true during the wet years with or without hail, but the hail caused leaf area loss across all water treatments. LAI during dry years more closely followed the magnitude of LAI in the hail years than the LAI during the wet years with no hail damage.
Linear regressions of corn GY and DMY with respect to growing season ETc using data from all years (2005-2012) produced functions that showed yield dependence on ETc, where $\mathrm{R}^{2}$ equaled 0.79 and 0.77 (table 4). GY and DMY were highly dependent on ETc during hail years (2005 and 2006) and during dry years (2008, 2011, and 2012) (table 4 and fig. 2). Moreover, the yield-ETc functions during hail years had slopes and y-intercepts similar to the function during dry years. Regressions from the wet years showed more variability in the data, possibly indicating more or less effectiveness of precipitation in conjunction with irrigation.

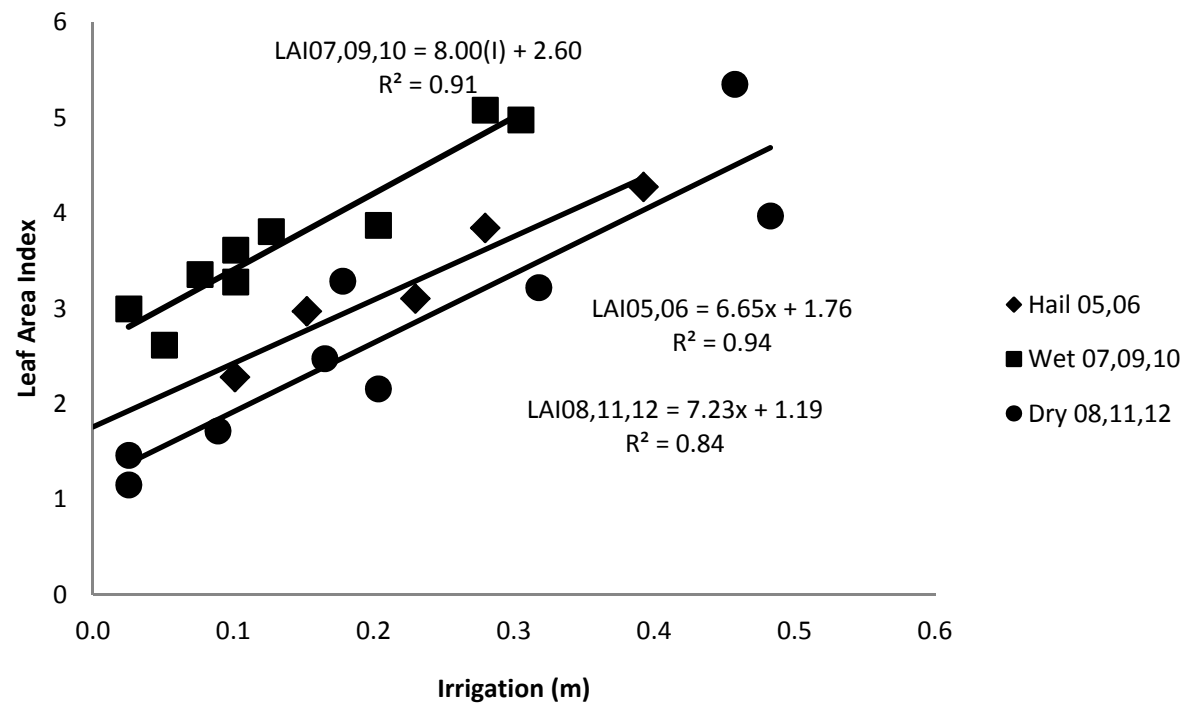

Figure 1. Leaf area index for years with above-average precipitation with hail events during vegetative growth in 2005 and 2006 , no hail in 2007 , 2009, and 2010, and dry years in 2008, 2011, and 2012. 
Table 4. Linear regressions of grain yields (GY) and dry matter yields (DMY) with respect to crop growing season evapotranspiration for corn and grain sorghum.

\begin{tabular}{lcccc}
\hline & $\begin{array}{c}\text { Slope } \\
\left(\mathrm{kg} \mathrm{m}^{-3}\right)\end{array}$ & $\begin{array}{c}\text { Y-Intercept } \\
\left(\mathrm{kg} \mathrm{m}^{-2}\right)\end{array}$ & $\mathrm{R}^{2}$ & $\begin{array}{c}\text { ETc-Intercept }^{[\mathrm{a}]} \\
(\mathrm{mm})\end{array}$ \\
\hline Corn GY-ETc & & & & \\
2005-2012 & 2.96 & -0.66 & 0.79 & 221 \\
Wet 07, 09, 10 & 3.12 & -0.60 & 0.65 & 194 \\
Hail 05, 06 & 2.92 & -0.79 & 0.91 & 270 \\
Dry 08, 12, 12 & 2.81 & -0.64 & 0.93 & 229 \\
\hline Corn DMY-ETc & & & & \\
2005-2012 & 4.50 & -0.83 & 0.77 & 185 \\
Wet 07, 09, 10 & 4.17 & -0.39 & 0.55 & 93 \\
Hail 05, 06 & 4.45 & -1.01 & 0.89 & 226 \\
Dry 08, 12, 12 & 4.12 & -0.79 & 0.95 & 191 \\
\hline Sorghum GY-ETc & & & & \\
2006-2012 & 2.55 & -0.44 & 0.75 & 173 \\
Wet 06, 07, 08, 09, 10 & $\mathbf{0 . 5 9}$ & $\mathbf{0 . 4 9}$ & $\mathbf{0 . 0 6}$ & No Int \\
Dry 11, 12 & 2.64 & -0.56 & 0.95 & 86 \\
\hline Sorghum DMY-ETc & & & & \\
2006-2012 & 3.67 & -0.23 & 0.71 & 63 \\
Wet 06, 07, 08, 09, 10 & $\mathbf{1 . 5 8}$ & $\mathbf{0 . 8 1}$ & $\mathbf{0 . 1 3}$ & No Int \\
Dry 11, 12 & 3.44 & -0.29 & 0.97 & 84 \\
\hline
\end{tabular}

Sorghum GY in 2005 were equal among all irrigation treatments as a result of a hail event, causing damage during vegetative growth and apparently capping the potential yields for all irrigation treatments (fig. 3). As a result, 2005 GY and DMY were excluded from further analysis. For sorghum, 2008 was characterized as a "wet" year even though cropping season precipitation was below average because: (1) cropping season precipitation for wheat was $220 \mathrm{~mm}$ above average, and (2) a hail event in 2007 damaged the wheat and no other crops. As a result, soil water content at the beginning of the 2008 sorghum growing season was the highest among all years (data not shown). Regressions of GY and DMY using data from all wet years combined showed no dependence on ETc (table 4) because there was not enough differentiation of yields across irrigation treatments; however, regressions of each year's yield data showed dependence on ETc, except for 2006 (regressions not shown). Regressions of GY and DMY during the dry years were strongly dependent on
ETc. Using sorghum GY and DMY data for all years except 2005 produced regressions with $\mathrm{R}^{2}$ values similar to those using all years for corn (table 4).

\section{YIELD RESPONSES TO IRRIGATION}

Corn GY and DMY were regressed with respect to irrigation using quadratic functions, except for DMY during hail years and dry years when linear functions provided better fits with the data (table 5). Using corn GY and irrigation data from all years produced a regression with high variability $\left(R^{2}=0.34\right)$. Separating wet, dry, and hail years produced three regressions with dramatic improvement in $\mathrm{R}^{2}$ values (table 5 and fig. 4). Hail during 2005 and 2006, with above-average precipitation, reduced corn GY more in the high-irrigation treatments than the low-irrigation treatments when compared with the wet years of 2007, 2009, and 2010. The regression for dry years was distinctly linear in contrast to curvilinear functions for wet years, indicating greater efficiency in using the combination of precipitation and stored soil water during the dry years.

Because sorghum yields were the same among all irrigation treatments during 2005 as a result of hail (fig. 5), 2005 results were excluded from the regressions. Using data from 2006-2012, sorghum GY and DMY response to irrigation (table 5) produced $\mathrm{R}^{2}$ values of 0.21 and 0.23 even though yields did increase in individual years. Separating wet and dry years into two quadratic regressions improved $\mathrm{R}^{2}$ values, with dry years showing more dependence on irrigation than wet years. Sorghum commonly follows wheat in dryland rotations in the region, as it did in this study, which confirmed that dryland sorghum production can be successful in wet years, even though some yield is lost compared with irrigated sorghum. In drought years, 2011 and 2012, dryland sorghum produced no grain and one-third of the DMY compared with wet years.

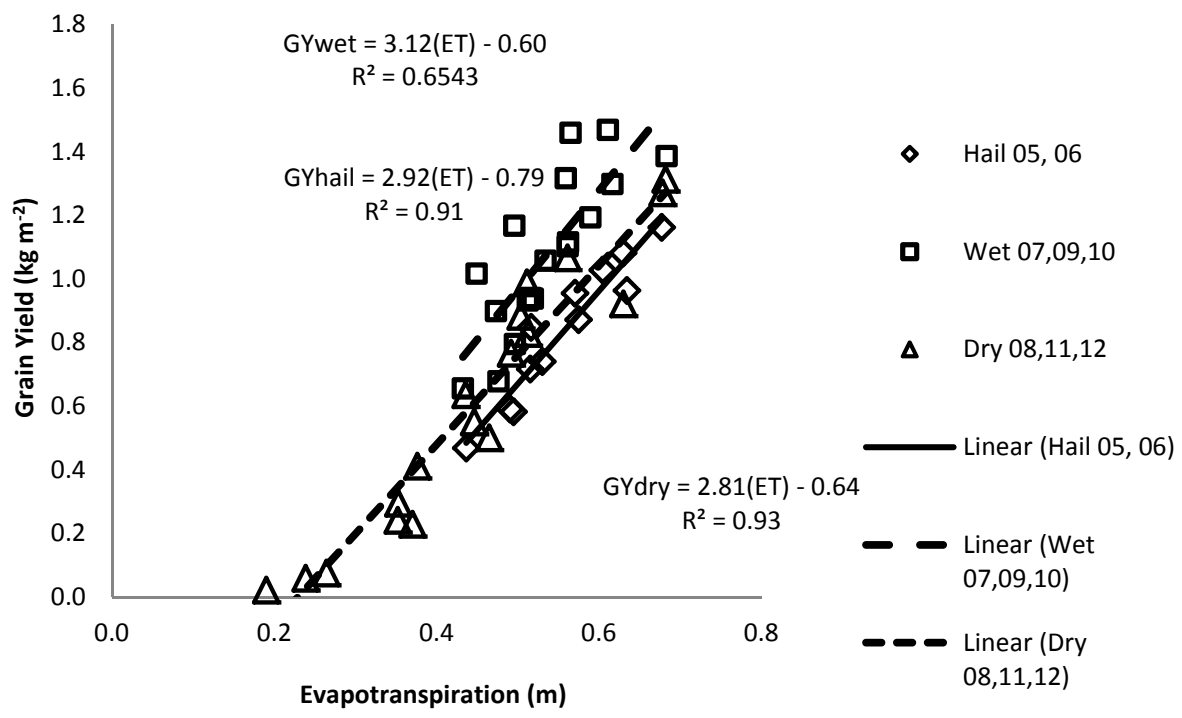

Figure 2. Corn grain yield vs. crop evapotranspiration. 


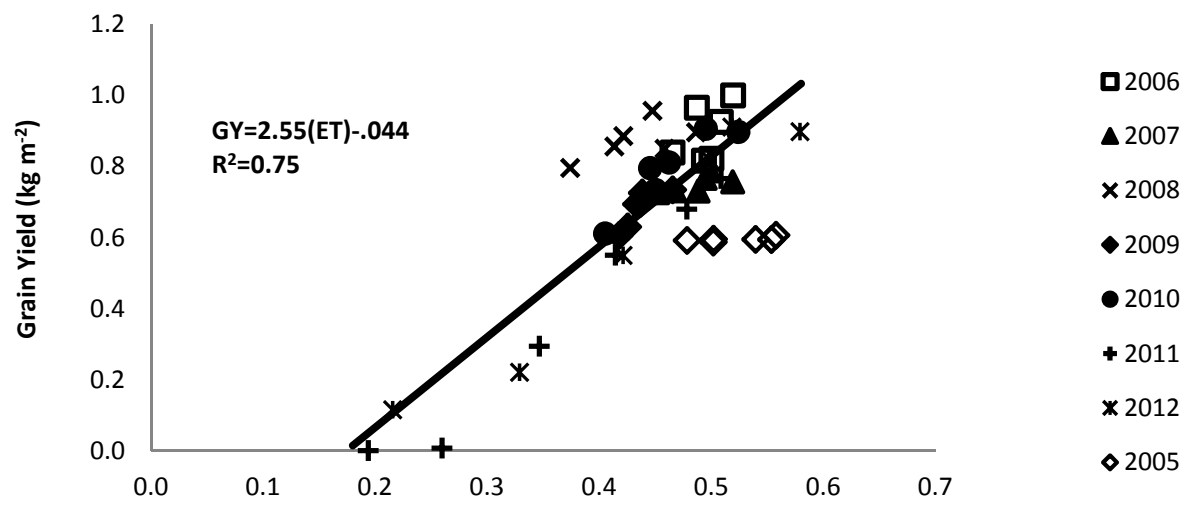

Evapotranspiration $(\mathrm{m})$

Figure 3. Sorghum grain yield vs. crop evapotranspiration for 2007-2012. Data from 2005 were not used in the regression due to a hail event.

Table 5. Quadratic regressions of grain yields (GY) and dry matter yields (DMY) with respect to crop growing season irrigation for corn and grain sorghum.

Coefficient* $\mathrm{I}^{2}$ Coefficient*I Y-Intercept

\begin{tabular}{|c|c|c|c|c|}
\hline & $\begin{array}{c}\text { Coefficient* } \mathrm{I}^{2} \\
\left(\mathrm{~kg} \mathrm{~m}^{-4}\right)\end{array}$ & $\begin{array}{l}\text { Coefficient*I } \\
\qquad\left(\mathrm{kg} \mathrm{m}^{-3}\right)\end{array}$ & $\begin{array}{l}\text { Y-Intercept } \\
\left(\mathrm{kg} \mathrm{m}^{-2}\right)\end{array}$ & $\mathrm{R}^{2}$ \\
\hline \multicolumn{5}{|c|}{ Corn GY-I } \\
\hline $2005-2012$ & -3.89 & 3.64 & 0.34 & 0.34 \\
\hline Wet $07,09,10$ & -9.91 & 6.22 & 0.45 & 0.92 \\
\hline Hail 05, 06 & -1.64 & 2.79 & 0.33 & 0.84 \\
\hline Dry $08,11,12$ & -1.54 & 3.57 & -0.06 & 0.87 \\
\hline \multicolumn{5}{|c|}{ Corn DMY-I } \\
\hline $2006-2012$ & -3.59 & 4.28 & 0.82 & 0.28 \\
\hline Wet $07,09,10$ & -12.77 & 8.62 & 0.99 & 0.81 \\
\hline Hail $05,06^{[\mathrm{a}]}$ & ------- & 3.26 & 0.77 & 0.89 \\
\hline Dry $08,11,12^{[\mathrm{a}]}$ & ------- & 4.15 & 0.15 & 0.9 \\
\hline \multicolumn{5}{|c|}{ Sorghum GY-I } \\
\hline $2006-2012$ & -5.58 & 2.84 & 0.48 & 0.21 \\
\hline Wet $06,07,08,09$, & & & & \\
\hline 10 & -3.30 & 1.72 & 0.63 & 0.39 \\
\hline Dry 11,12 & -2.34 & 3.66 & 0.02 & 0.87 \\
\hline \multicolumn{5}{|c|}{ Sorghum DMY-I } \\
\hline $2006-2012$ & -11.09 & 4.95 & 105 & 0.23 \\
\hline Wet $06,07,08,09$, & & & & \\
\hline 10 & -8.22 & 3.91 & 1.26 & 0.56 \\
\hline Dry 11,12 & -1.77 & 4.51 & 0.41 & 0.95 \\
\hline
\end{tabular}

[a] Linear regressions.

\section{ECONOMIC TRADEOFFS WITH CORN AND SORGHUM Production}

Corn is more dependent on irrigation than sorghum prompting the question of whether or not sorghum could be substituted for corn with limited water supplies. Economic evaluations are needed in addition to production response to irrigation. Corn could be rotated corn (C-C), sorghum (C-S), or wheat (C-W) and sorghum could also be rotated with wheat $(\mathrm{S}-\mathrm{W})$. Continuous sorghum $(\mathrm{S}-\mathrm{S})$ is not common because of weed control issues but it was examined along with the rest of the rotations. By definition
RNR for C-C with $0.460 \mathrm{~m}$ precipitation is 1 (table 6). RNR values decrease as precipitation decreases and the NR potential of each rotation decrease. During years with below-average precipitation $(0.280 \mathrm{~m})$ or average precipitation $(0.460 \mathrm{~m})$, maximum RNR for each crop rotation occurs with different amounts of irrigation (table 6 and figs. 6 and 7). Irrigation amounts to achieve maximum RNR increase in order from S-W through S-S, C-W, C-S and $\mathrm{C}-\mathrm{C}$. At low amounts of irrigation the RNR for C-C falls below the other crop rotations. The "break-even" RNR for C-C and other rotations increase in the same order of rotations as the maximum RNR values, but it takes less irrigation for the "break-even" points with more precipitation.

Farmers should not choose crop rotations based solely on NR and yield response to irrigation. Corn is more susceptible to stress from soil water depletions than sorghum or wheat, causing corn yields to vary more in dry years than wet years. Crop management systems, particularly weed control, have been refined for continuous corn but not for continuous sorghum. $\mathrm{C}-\mathrm{W}$ rotations can be appropriate when water supplies are limited, because more irrigation can be applied to corn than wheat with both crops achieving maximum NR. This approach leads to less yield variability from year to year for corn which contributes more NR to the rotation. Sorghum usually is harvested later in the fall than corn, leaving less time for fall growth of wheat planted immediately after harvest in the S-W rotation. Even though sorghum has less NR potential than corn, sorghum can tolerate water stress more readily than corn. Making decisions on cropping strategies is not straightforward because yield response to irrigation, susceptibility to water stress, economic returns, and management factors all influence successful outcomes. 


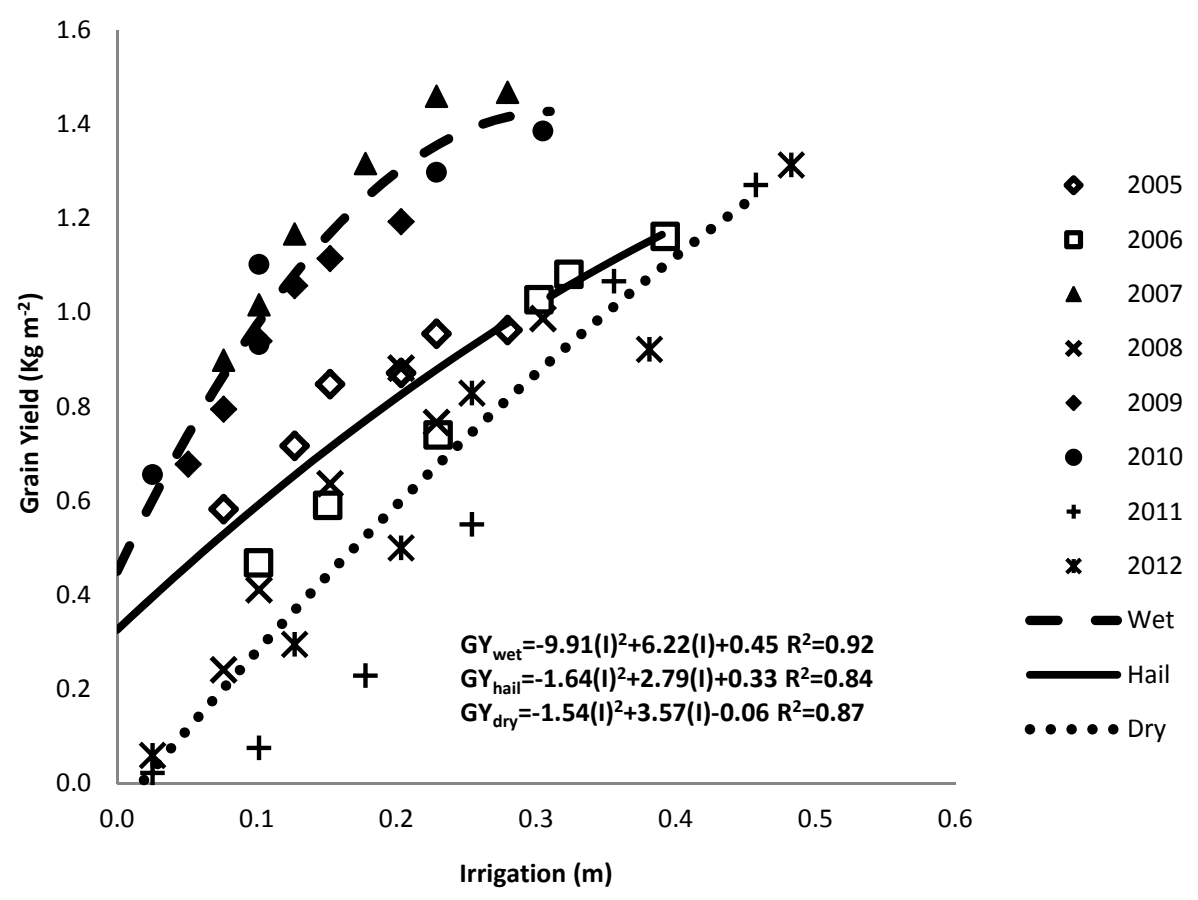

Figure 4. Corn grain yield vs. irrigation for hail years $(2005,2006)$, wet years $(2007,2009,2010)$, and dry years $(2008,2011,2012)$.

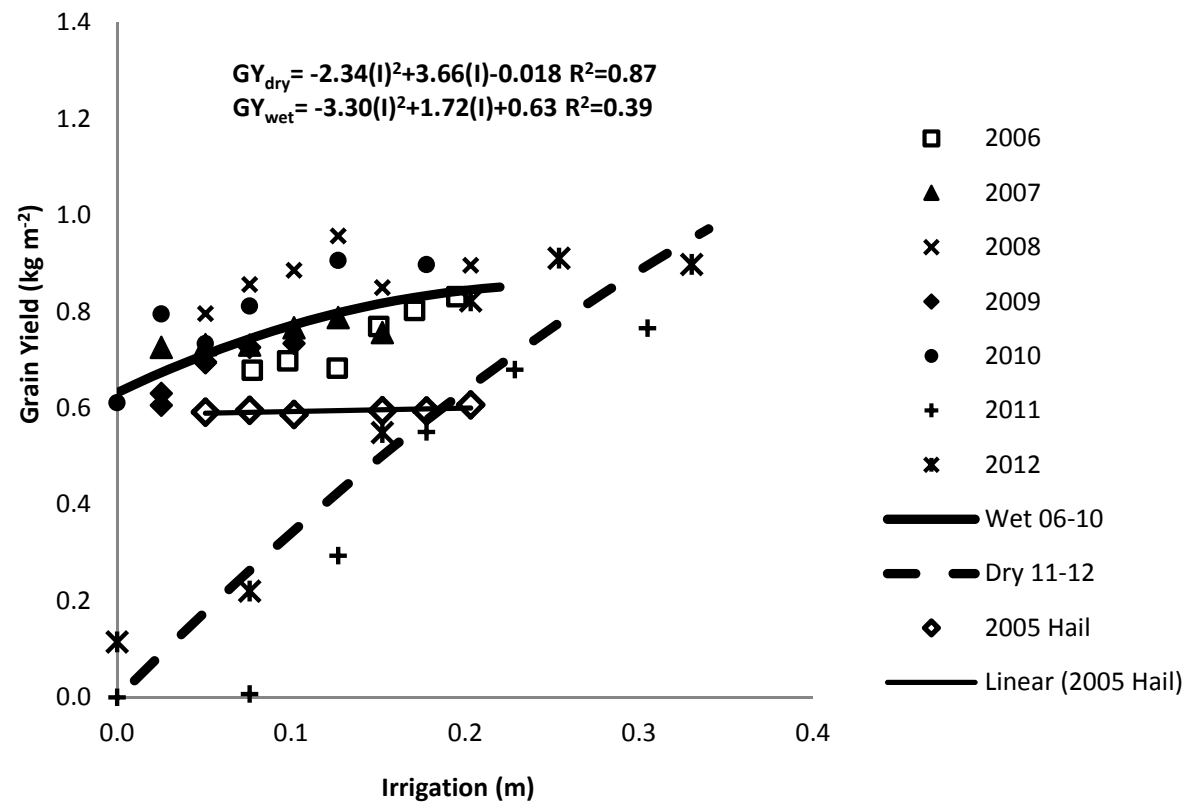

Figure 5. Sorghum grain yield vs. irrigation for years with above- and below-average precipitation. Hail on wheat in 2007 caused sorghum GY response to resemble wet years.

\section{SUMMARY}

Cropping season precipitation, the water that potentially contribute crop yields the maturity of one crop to the next, was $95 \%$ of the 30 -average for corn and $95 \%$ for sorghum during the eight years (2005-2012) of the field study, but precipitation during two of the years (2011-2012) was 63\% of the 30-year average. Hail events in 2005 and 2006 reduced corn's leaf area during late vegetative growth and its potential yield. The same 2005 hail event damaged the sorghum to the extent that grain yields were equal among all irrigation treatments. Separating results for corn by wet years, dry years, and hail years produced yield: ETc regressions where the dry years and hail years had similar slopes which were both less than the slope during the wet years, possibly because the leaf area indices across irrigation treatments were similar for dry and hail years. Sorghum GY and DMY increased with irrigation during individual wet years, but the pooled yield data during the wet years (2006-2010) did not show dependence on ETc. Combining either corn or sorghum yield data from all years 
Table 6. Irrigation to achieve maximum net return (RNR) for each rotation and irrigation needed for continuous corn RNR to exceed RNR of other rotations.

\begin{tabular}{|c|c|c|c|}
\hline Crop Rotation & $\begin{array}{c}\text { Maximum } \\
\text { RNR }\end{array}$ & $\begin{array}{c}\text { Irrigation }^{[\mathrm{a}]} \\
(\mathrm{m})\end{array}$ & $\begin{array}{c}\text { Irrigation }^{[\mathrm{b}]} \\
(\mathrm{m})\end{array}$ \\
\hline \multicolumn{4}{|c|}{$0.28 \mathrm{~m}$ Precipitation } \\
\hline Sorghum-Wheat & 0.15 & 0.4 & 0.22 \\
\hline Sorghum-Sorghum & 0.18 & 0.46 & 0.26 \\
\hline Corn-Wheat & 0.43 & 0.45 & 0.30 \\
\hline Corn-Sorghum & 0.59 & 0.55 & 0.34 \\
\hline Corn-Corn & 0.86 & $>0.54$ & --- \\
\hline \multicolumn{4}{|c|}{$0.46 \mathrm{~m}$ Precipitation } \\
\hline Sorghum-Wheat & 0.21 & 0.25 & 0.04 \\
\hline Sorghum-Sorghum & 0.43 & 0.33 & 0.13 \\
\hline Corn-Wheat & 0.57 & 0.35 & 0.14 \\
\hline Corn-Sorghum & 0.73 & 0.38 & 0.18 \\
\hline Corn-Corn & 1.00 & 0.45 & --- \\
\hline
\end{tabular}

produced linear regressions of yields and irrigation that were highly variable. Individual regressions for corn in wet years, hail years, and dry years illustrated high dependence of yields on irrigation and high $\mathrm{R}^{2}$ values. Sorghum yields were highly dependent on irrigation during dry years, but they were highly variable with respect to irrigation during wet years. These results reinforce the reasons for growing corn when adequate irrigation is available and for growing sorghum in dryland cropping systems in the region.

Choosing between corn and sorghum for crop production with very limited water supplies for irrigation also include consideration of net economic returns (NR), gross income-operating expenses. Possible crop rotations are monoculture corn $(\mathrm{C}-\mathrm{C})$ and sorghum $(\mathrm{S}-\mathrm{S})$ and rotations with wheat (C-W and S-W). Rotations of all crops with corn (C-S and C-W) have higher NR potential than those with sorghum (S-S and S-W). Maximum NR for each rotation takes different amounts of irrigation. NR for each crop rotation increases with increasing precipitation. The amount of irrigation needed for the NR of C-C to equal the NR ("break even" point) is different for other crop rotations.

Corn is susceptible to water stress, but sorghum can tolerate more water stress. The crops react differently as irrigation decreases, as shown by trends in GY and DMY. Continuous corn, the predominant irrigated crop in the region, and sorghum, the predominant dryland crop following winter wheat, can play a role in cropping systems when irrigation supplies are limited. In years with average precipitation, NR from corn dominates other crops when irrigation is minimal, but other crop rotations come into play economically when precipitation is well below average. A rotation of corn and sorghum, where some of the irrigation can be shifted from sorghum to corn, may be an alternative if other crop management factors, especially weed control, can be successful.

\section{ACKNOWLEDGEMENTS}

This research was supported in part by the Ogallala Aquifer Program, a consortium of the USDA Agricultural Research Service, Kansas State University, Texas AgriLife Research, Texas AgriLife Extension Service, Texas Tech University, and West Texas A\&M University. This is contribution number 14-226-J from the Kansas Agricultural Experiment Station.

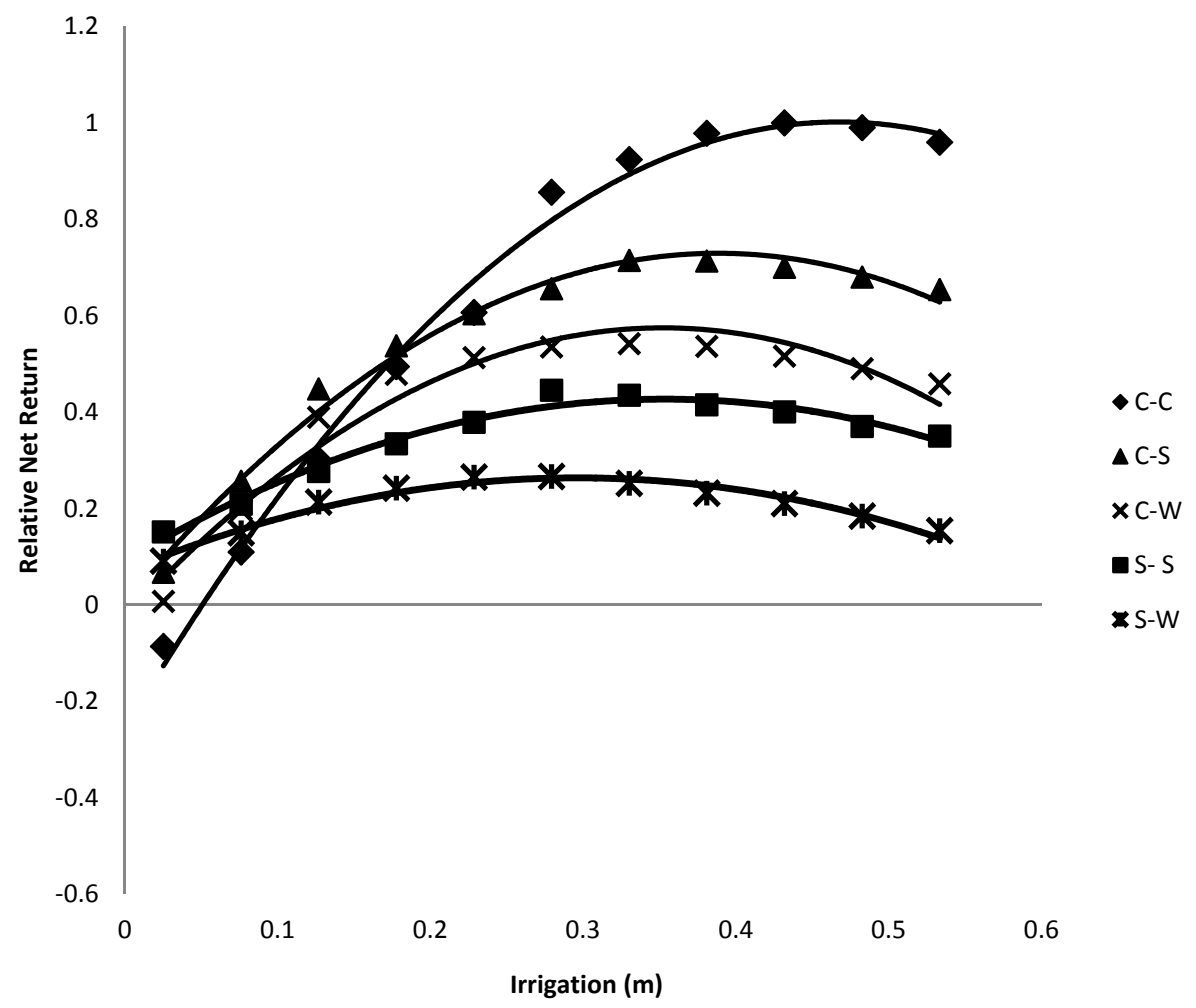

Figure 6. Relative net return (net return $\div$ maximum net return from corn) from continuous corn (C-C), continuous sorghum (S-S), cornsorghum (C-S), corn-wheat $(C-W)$, and sorghum-wheat $(S-W)$ in years with annual precipitation of $460 \mathrm{~mm}$. 


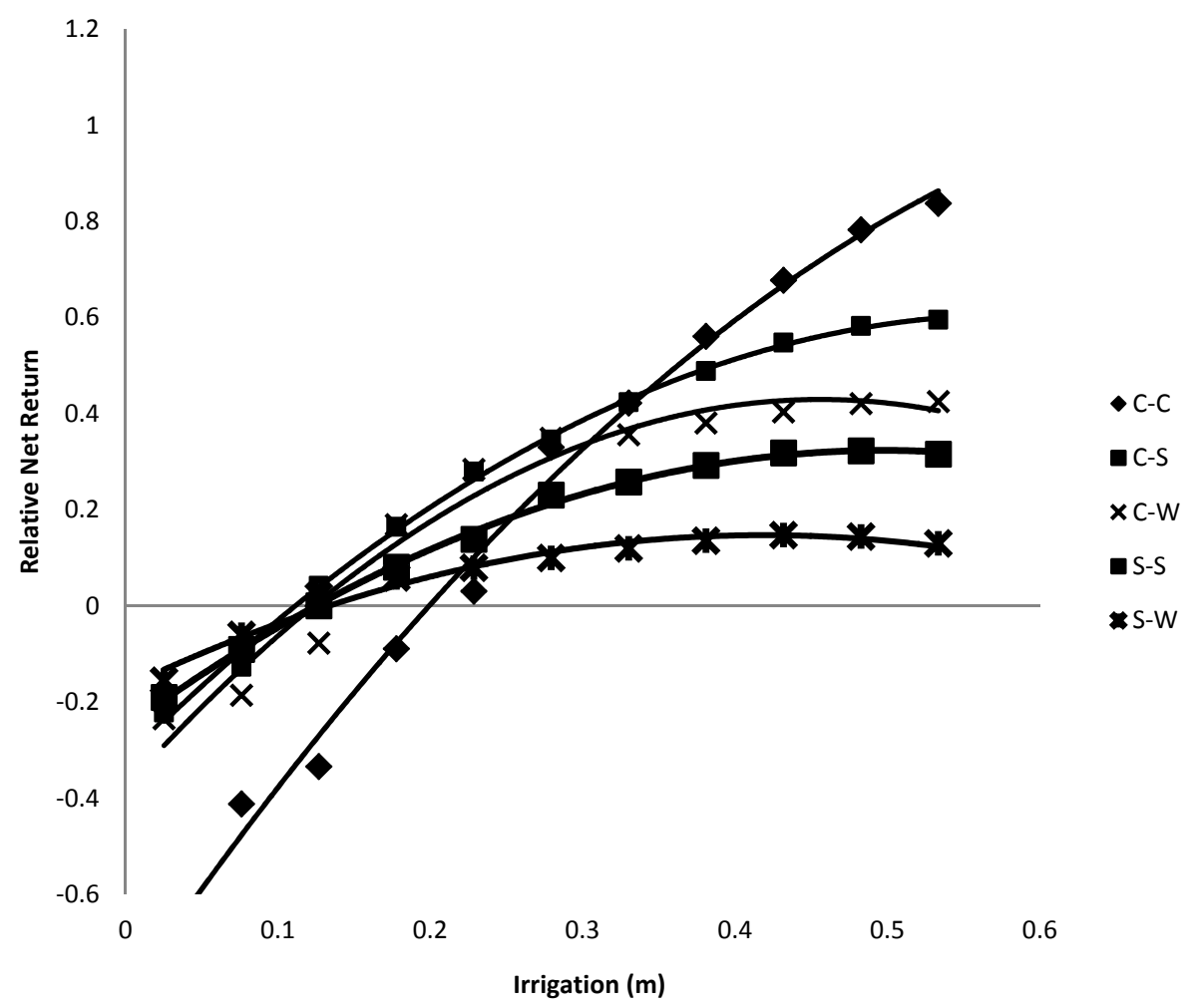

Figure 7. Relative net return (net return $\div$ maximum net return from corn) from continuous corn (C-C), continuous sorghum (S-S), cornsorghum (C-S), corn-wheat (C-W), and sorghum-wheat (S-W) in years with annual precipitation of $280 \mathrm{~mm}$.

\section{REFERENCES}

Allen, R. R., \& Musick, J. T. (1993). Planting date, water management, and maturity length relations for irrigated grain sorghum. Trans. ASABE, 36(4), 1123-1129. http://dx.doi.org/10.13031/2013.28443.

Bordovsky, J. P., \& Lyle, W. M. (1996). LEPA Irrigation of grain sorghum with varying water supplies. Trans. ASABE, 39(6), 2033-2038. http://dx.doi.org/10.13031/2013.27706.

Colaizzi, P. D., Evett, S. R., \& Howell, T. A. (2004). Comparisons of SDI, LEPA, and spray irrigation performance for grain sorghum. Trans. ASABE, 47(5), 1477-1492. http://dx.doi.org/10.13031/2013.17628.

Currie, R. S., \& Klocke, N. L. (2008). Impact of irrigation and hail on Palmer Amaranth (Amaranthus palmeri) in Corn (Zea mays). Weed Technol., 22(3), 448-552. http://dx.doi.org/10.1614/WT07-173.1.

Evett, S. R., \& Steiner, J. L. (1995). Precision of neutron scattering and capacitance-type water content gauges from field calibration. SSSA J., 59(4), 961-968. http://dx.doi.org/10.2136/sssaj1995.03615995005900040001x.

Howell, T. A., Copeland, K. S., Schneider, A. D., \& Dusek, D. A. (1989). Sprinkler irrigation management for corn-southern Great Plains. Trans. ASABE, 32(1), 147-160. http://dx.doi.org/10.13031/2013.30974.

Howell, T. A., Yazar, A., Schneider, A. D., Dusek, D. A., \& Copeland, K. S. (1995). Yield and water use efficiency of corn in response to LEPA irrigation. Trans ASABE, 39(6), 17371747. http://dx.doi.org/10.13031/2013.28001.

Kincaid, D. C., \& Heermann, D. F. (1974). Scheduling Irrigation Using A Programmable Calculator (Vols. NC-12). Washington, D.C.: USDA-ARS.
Klocke, N. L., Currie, R. S., Stone, L. R., \& Bolton, D. A. (2010). Planning for deficit irrigation. J. Appl. Eng. Agric., 26(3), 405412. http://dx.doi.org/10.13031/2013.29955.

Klocke, N. L., Currie, R. S., Tomsicek, D. J., \& Koehn, J. (2011). Corn yield response to deficit irrigation. Trans. ASABE, 54(3), 931-940. http://dx.doi.org/10.13031/2013.37118.

Klocke, N. L., Currie, R. S., Tomsicek, D. J., \& Koehn, J. (2012). Sorghum yield response to deficit irrigation. Trans. ASABE, 55(3), 947-955. http://dx.doi.org/10.13031/2013.41526.

Klocke, N. L., Hunter Jr., C., \& Alam, M. (2003). Application of a linear move sprinkler system for limited irrigation research. ASAE Paper No. 032012 (p. 13). St. Joseph, Mich.: ASABE. http://dx.doi.org/10.13031/2013.13989.

Klocke, N. L., Payero, J. O., \& Schneekloth, J. P. (2007). Longterm response of corn to limited irrigation and crop rotation. Trans. ASABE, 50(6), 2117-2124. http://dx.doi.org/10.13031/2013.24113.

Klocke, N. L., Stone, L. R., Clark, G. A., Dumler, T. J., \& Briggeman, S. (2006). Water allocation model for limited irrigation. J. Appl. Eng. Agric., 22(3), 381-389. http://dx.doi.org/10.13031/2013.20458.

Lamm, F. R., Rogers, D. H., \& Manges, H. L. (1994). Irrigation scheduling with planned soil water depletion. Trans. ASABE, 37(5), 1491-1497. http://dx.doi.org/10.13031/2013.28232.

Lyle, W. M., \& Bordovsk, J. P. (1995). LEPA corn irrigation with limited water supplies. Trans. ASABE, 38(2), 455-462. http://dx.doi.org/10.13031/2013.27853.

Martin, D. L., Gilley, J. R., \& Supalla, R. J. (1989). Evaluation of irrigation planning decisions. J. Irrig. Drainage Div. ASCE, 115(1), 58-77. http://dx.doi.org/10.1061/(ASCE)07339437(1989)115:1(58). 
Schneider, A. D., \& Howell, T. A. (1995). Grain sorghum response to sprinkler application methods and system capacity. Trans. ASABE, 38(6), 1693-1697. http://dx.doi.org/10.13031/2013.27996.

Schneider, A. D., \& Howell, T. A. (1998). LEPA and spray irrigation of corn-southern High Plains. Trans. ASABE, 41(5), 1391-1396. http://dx.doi.org/10.13031/2013.17313.
Stone, L. R., Schlegel, A. J., Kahn, A. H., Klocke, N. L., \& Aiken, R. M. (2006). Water supply: Yield relationships developed for study of water management. J. Natural Res. Life Sciences Education, 35, 161-173. 